\title{
DO WE NEED BIOPSY FOR ALL PALPABLE BREAST MASSES WITH BIRADS 4 ASSESSMENT SCORE? A TERTIARY CANCER CENTER EXPERIENCE
}

\author{
Mohapatra S.K. ', Nayak R.B.2
}

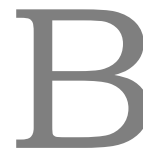

reast Imaging Reporting and Data System (BI-RADS) is a comprehensive guideline to standardize breast imaging reporting and as per its recommendations, any lesion with likelihoods of malignancy greater than 2\% (BI-RADS 4 and 5) are deemed as suspicious and tissue diagnosis is recommended.

Purpose. To assess the positive predictive value (PPV) for breast cancer in BI-RADS categories $4 \mathrm{a}, 4 \mathrm{~b}$, and $4 \mathrm{c}$. To evaluate the impact of demographic, clinical presentation and mammographic morphological variables influencing PPV values in BI-RADS 4 subgroups. Defining low-risk parameters where close follow up can be recommended rather than biopsy.

Materials and methods. Retrospective study on medical records of 123 patients with a BI-RADS 4 score regarding demographics, clinical presentation, mammography, and biopsy are performed. Predictive values and Odds ratio are calculated using logistic regression and chi-square analysis.

Results. PPV for BI-RADS subcategories $4 a$, $4 b$ and $4 c$, were $34 \%, 89 \%$ and $97 \%$, respectively. BI-RADS $4 \mathrm{c}$ patients tend to be older $(50.2+12.2$ years $)$ with larger mass $(44+16 \mathrm{~mm})$ at presentation than $4 \mathrm{a}$. Postmenopausal status and advanced patient age are seen more associated with malignancy outcomes in the BI-RADS 4a sub-category. Benign outcomes are seen in all cases with the BI-RADS 4a subcategory in less than 40 years of age group.

Conclusion. Immediate biopsy is recommended for all lesions with BI-RADS $4 \mathrm{~b}, 4 \mathrm{c}$ and $4 \mathrm{a}$ score with age more than 40 years but additional imaging or follow up can be advised in patients less than 40 years in BI-RADS 4 a subgroup. A higher rate of observed PPV in BI-RADS $4 \mathrm{a}$ and $4 \mathrm{~b}$ categories in the present study could be due to the subjectiveness of the category assignment.

Keywords: BI-RADS 4, breast carcinoma, mammography, microcalcification, spiculation

Corresponding author: Mohapatra S.K., e-mail: drsuvendumohapatra@gmail.com

For citation: Mohapatra S.K., Nayak R.B. Do we need biopsy for all palpable breast masses with birads 4 assessment score? A tertiary cancer center experience. REJR 2020; 10(2):93-101. DOI:10.21569/2222-7415-2020-10-2-93-101.

Received: $\quad 03.05 .20 \quad$ Accepted: $\quad 17.06 .20$

\section{НЕОБХОАИМА АИ БИОПСИЯ АЛЯ ВСЕХ ПААЬПИРУЕМЫХ ОБРАЗОВАНИЙ МОЛОЧНОЙ ЖЕАЕЗЫ С ОЦЕНКОЙ ВIRADS 4? ОПЫТ ОНКОЛОГИЧЕСКОГО ЦЕНTPA ТРЕTЬEГО ПОРЯАКА}

\author{
Мохапатра C.K. ${ }^{1}$, Наяк P.Б.2
}

1- AHPGIC, Mangalabag. 2- Medical College. Cuttack, Odisha, India. 
сии.

Цели. Оценить положительную прогностическую ценность (PPV) рака молочной железы в категориях BI-RADS 4a, 4b и 4c. Оценить влияние демографических, клинических и маммографических морфологических переменных, влияющих на значения PPV в подгруппах BI-RADS 4. Опредемить параметры низкого риска, при которых может быть рекомендовано набцюдение, а не биопсия.

Материалы и методы. Проведено ретроспективное исследование медицинских карт 123 пациентов с оценкой BI-RADS 4 в отношении демографии, клинической картины, данных маммографии и биопсии. Прогностические значения и отношение шансов рассчитываются с помощью могистической регрессии и анализа хи-квадрат.

Результаты. PPV дмя BI-RADS подкатегорий 4a, 4b и 4c составили 34\%, 89\% и 97\%, соответственно. Пациенты с BI-RADS 4c, как правимо, старше $(50,2+12,2$ года) с большей массой тела (44+16 мм) с категорией 4а. Постменопаузальный статус и пожимой возраст пациентов, как видно, больше связаны со злокачественными исходами новообразований в подкатегории BI-RADS 4a. Доброкачественные исходы наблюдаются во всех случаях с подкатегорией BI-RADS 4а в возрастной группе менее 40 мет.

Выводы. Немедменная биопсия рекомендуется дмя всех поражений с оценкой BIRADS 4b, 4c и 4а в возрасте более 40 мет, но дополнительная визуализация или последующее наблюдение могут быть рекомендованы пациентам менее 40 мет в подгруппе BI-RADS 4a. Более высокая частота наблюдаемых PPV в категориях BI-RADS 4a и 4b в настоящем исследовании может быть обусловлена субъективностью присвоения категории.

К^ючевые слова: BI-RADS 4, рак молочной железы, маммография, микрокальцификация, спикулы.

Контактный автор: Мохапатра С.K., e-mail: drsuvendumohapatra@gmail.com

Для иитирования: Мохапатра С.К., Наяк Р.Б. Необходима ли биопсия для всех пальпируемых образований молочной железы с оченкой birads 4? Опьт онкологического иентра третьего порядка. REJR 2020; 10(2):93-101. DOI:10.21569/2222-7415-202010-2-93-101.
Статья получена:
03.05.20
Статья принята:
17.06.20

I

\section{ntroduction.}

Breast cancer is one of the leading cancers in females worldwide with an age-adjusted incidence rate of 25.8 per 1 lakh population in India [1]. Approximately only $10 \%$ of the patient presenting with breast lumps will have malignancy so it is important to have a preoperative diagnostic evaluation which in turn will reduce unnecessary interventions [2]. Mammography is the primary imaging modality for breast cancer screening \& diagnosis due to its wider availability and cost-effectiveness [3]. The American College of Radiology Breast Imaging Reporting and Data System (BI-RADS) is a comprehensive quality assurance tool designed to standardize mammography reporting, reduce confusion regarding breast imaging interpretation and its possible management recommendations, and also helps in outcomes monitoring for mammography [4]. Based on the likelihood of malignancy and its management it has 1 to 6 categories of final assessment (table 1).

BI-RADS 5 category poses a less diagnostic dilemma in mammography as finding is almost overt like distinctly visualized irregular mass, spiculation, architectural distortion or pleomorphic microcalcifications. But over-diagnosis forms a serious concern in BI-RADS 4 which encompasses a huge heterogeneous group with likelihood malignancy rates ranging from 3 to $94 \%$. With the use of BI-RADS assessment categories and its management recommendations, breast imaging findings any lesion with likelihoods of malignancy greater than $2 \%$ (category 4 and 5) are deemed as suspicious lesion and tissue diagnosis is recommended. However, benefits of immediate tissue diagnosis have been debated in the subgroup of BI-RADS 4 a concerning potential harms such as overdiagnosis of indolent lesions, the additional cost of testing, possible radiation and anxiety associated with falsely positive screening/diagnostic mammography and erroneous sense of security from falsely negative mammograms. [5,6]. Given the low cancer risk among category $4 \mathrm{~A}$ and the wide range of cancer risk in category 4B lesions, some researchers advocate for 
Table №1. BI-RADS final assessment scoring system derived from BI-RADS atlas 5th edition, NA-not applicable

\begin{tabular}{|c|c|c|}
\hline Category & Definition & Likelihood of malignancy (\%) \\
\hline $\mathbf{0}$ & $\begin{array}{c}\text { Incomplete study / Need additional imag- } \\
\text { ing evaluation }\end{array}$ & N/A \\
\hline 1 & Normal breast & 0 \\
\hline 2 & Benign finding needs no further action & 0 \\
\hline 3 & $\begin{array}{l}\text { Probably benign,short interval follow up } \\
\text { recommended }\end{array}$ & $\leq 2$ \\
\hline 4 & Suspicious finding - Biopsy advised & $\begin{array}{c}\text { 4a-low suspicion for malignancy }(>2 \text { to } \leq 10) \\
\text { 4b-moderate suspicion for malignancy }(>10 \text { to } \leq 50) \\
\text { 4c-high suspicion for malignancy }(>50 \text { to }<95)\end{array}$ \\
\hline 5 & $\begin{array}{l}\text { Highly suggestive of malignancy, requir- } \\
\text { ing biopsy \& further action }\end{array}$ & $\geq 95$ \\
\hline 6 & Biopsy proved malignant lesion & $\mathrm{N} / \mathrm{A}$ \\
\hline \multicolumn{2}{|c|}{ Inclusion criteria } & Exclusion criteria \\
\hline $\begin{array}{l}\text { All patier } \\
\text { with avai } \\
\text { known pa }\end{array}$ & $\begin{array}{l}\text { with BI-RADS } 4 \text { assessment score } \\
\text { able clinical, demographic details and } \\
\text { ological outcomes. }\end{array}$ & $\begin{array}{l}\text { 1. All other BI-RADS assessment scores. } \\
\text { 2. Non available clinical, pathological and fol- } \\
\text { low up records. }\end{array}$ \\
\hline
\end{tabular}

different approaches to stratify and manage patients who fall into these categories. Flowers et al propose reclassifying BI-RADS $4 \mathrm{~A}$ as low-risk lesions that can be clinically evaluated and followed rather than immediately sampled via biopsy [7]. Data from an earlier study on the Asian population suggest that reduced sensitivity and positive predictive values of mammograms due to smaller breast volume and relatively denser breast than their western counterparts, so the applicability of BI-RADS 4 predictability and its management recommendation must be evaluated in Indian context [8].

In the present study, we aim

1. To determine the PPV of BI-RADS category $4 \mathrm{a}, 4 \mathrm{~b}$, and $4 \mathrm{c}$ regarding cancer outcome.

2. To evaluate the impact of demographic, clinical presentation and mammographic morphological variables influencing PPV values in BIRADS 4 subgroups.

3. Evaluate the possible use of these clinicodemographic and mammographic morphological variables as to define a low-risk group which can be used along with BI-RADS scoring in resources limited scenarios in low and moderately suspicious cases guiding whether an individual would be a better candidate for active surveillance rather than undergoing urgent biopsy.
Materials and methods.

A retrospective record based analytical study was conducted in the department of radiodiagnosis after institutional review board approved the data collection and analysis. The sampling technique was purposive that is of nonprobability type. By careful review of the case records, mammogram, histo-pathological, operative records and reporting database of our hospital from August 2019 to April 2020, we have shortlisted 140 patients with BI-RADS-4 assessment, out of which 17 patients' records were discarded due to paucity of the follow-up records and histopathological outcome. Case records were shortlisted based on the inclusion and exclusion criteria (table 2).

Finally, 123 (N) patients' records with a BIRADS score of 4 had been finalized for analysis in the present study.

Senographae Pristina (GE medical system SCS France) digital mammography unit was used for mammography purposes. All mammograms were evaluated by a set of two 5-megapixel (5MP BARCO) medical-grade monitors. Mediolateral oblique (MLO) and craniocaudal (CC) views were considered as standard for all patients but additional views like exaggerated view and axillary views were also included as and when required. 
Table №3. BI-RADS 4 subgroups and its association with malignant outcomes, PPV=positive predictive value $O R=$ Odds Ratio, $C I=$ confidence interval.

\begin{tabular}{|c|c|c|c|c|}
\hline BIRADS SCORE & PPV (\%) & ODDS RATIO(OR) & $95 \% \mathrm{CI}$ & P VALUE \\
\hline BIRADS 4A & 34 & 0.044 & 0.015 to 0.123 & $<0.0001$ \\
\hline BIRADS 4B & 89 & 4.75 & 1.78 to 12.66 & 0.0018 \\
\hline BIRADS 4C & 97 & 15.246 & 1.98 to 117 & 0.0088 \\
\hline
\end{tabular}

Table №4. Age group distribution among BIRADS 4 subgroups and its outcome.

\begin{tabular}{|c|c|c|c|c|c|c|}
\hline Age Group & $\begin{array}{l}\text { BI-RADS } \\
\text { 4a/malignant }\end{array}$ & \multicolumn{2}{|c|}{$\begin{array}{l}\text { BI-RADS } \\
\text { 4b/malignant }\end{array}$} & \multicolumn{2}{|c|}{$\begin{array}{l}\text { BI-RADS } \\
\text { 4c/malignant }\end{array}$} & Total/malignant \\
\hline$\leq 40 \mathrm{yrs}$ & $12 / 0$ & \multicolumn{2}{|l|}{$17 / 15$} & \multicolumn{2}{|l|}{$8 / 8$} & $37 / 23$ \\
\hline $41-50$ & $16 / 6$ & \multicolumn{2}{|l|}{$21 / 20$} & \multicolumn{2}{|l|}{$8 / 8$} & $45 / 34$ \\
\hline $51-60$ & $6 / 5$ & \multicolumn{2}{|l|}{$13 / 10$} & \multicolumn{2}{|l|}{$10 / 10$} & $29 / 25$ \\
\hline $61-70$ & $2 / 1$ & \multicolumn{2}{|l|}{$3 / 3$} & \multicolumn{2}{|l|}{$4 / 4$} & $9 / 8$ \\
\hline$>70$ & $0 / 0$ & \multicolumn{2}{|l|}{$1 / 1$} & \multicolumn{2}{|l|}{$2 / 1$} & $3 / 2$ \\
\hline Total & $36 / 12$ & \multicolumn{2}{|l|}{$55 / 49$} & \multicolumn{2}{|l|}{$32 / 31$} & $123 / 92$ \\
\hline \multirow{2}{*}{\multicolumn{3}{|c|}{ Clinical presentations }} & \multirow{2}{*}{\multicolumn{2}{|c|}{ Total }} & \multirow{2}{*}{\multicolumn{2}{|c|}{ Malignant }} \\
\hline & & & & & & \\
\hline \multicolumn{2}{|c|}{ Lump } & & \multicolumn{2}{|l|}{123} & \multicolumn{2}{|l|}{92} \\
\hline \multicolumn{2}{|l|}{ Pain } & & \multicolumn{2}{|l|}{5} & \multicolumn{2}{|l|}{1} \\
\hline \multicolumn{2}{|l|}{ Discharge } & & \multicolumn{2}{|l|}{3} & \multicolumn{2}{|l|}{1} \\
\hline \multicolumn{2}{|l|}{ Skin changes } & & \multicolumn{2}{|l|}{32} & \multicolumn{2}{|l|}{25} \\
\hline
\end{tabular}

Mammography images were reviewed retrospectively by a single radiologist (with 10 years of experience of breast imaging) who was unaware of the histopathological outcome, demography and clinical data while reporting. Mammography structured reporting and analysis was based on guidelines from BI-RADS 5th edition detailing regarding breast density, mass shape, size, margin, location, mass density, calcifications, asymmetry, satellite lesions, skin thickening, lymph node, and architectural distortion. The shape of the mass lesion was further classified into round, oval and irregular and the mass margin classified into wellcircumscribed, microlobulated, masked, indistinct and spiculated. BI-RADS final assessment scoring 4 was further subdivided into $4 \mathrm{a} 4 \mathrm{~b}$ and $4 \mathrm{c}$ based on the degree of suspiciousness. In all these patients histopathological reports were retrieved which includes core needle, image-guided and post-surgical biopsy. The outcome of histopathology was classified as positive and negative for malignancy which was treated as the outcome of the present study for predictive analysis. The clinical and demographic characteristics of patients like age, family history (FH), menopause, lump, discharge, pain and skin changes were noted. All these data were entered into a predefined proforma by the researchers in Microsoft Excel format. The data were doubly cross-checked for any duplicate or missing data by other independent researchers. Qualitative data like mammography morphology and clinical features had been described in terms of frequency and proportions. Quantitative data like age and mass size described in terms of mean, SD, maximum and minimum. The odds ratio (OR), and $\mathrm{p}$ values were calculated using logistic regression and chi-square analysis. The PPV value of an individual morphological variable and BI-RADS sub scoring had been estimated for malignancy outcome. Statistical analysis was performed using SPSS-v.20. For value to be significant $\mathrm{P}$-value $<0.05$ had been considered at a $95 \%$ confidence limit and appropriate degrees of freedom.

Results.

A total of 123 women with BI-RADS 4 score were sub-classified into 4A (29.4\%), 4B (44.8\%) and $4 \mathrm{C}(26.8 \%)$ with $92(74.8 \%)$ malignant and 
Table №6. Breast density division among BI-RADS subgroups and its histopathological outcomes.

\begin{tabular}{c|c|c|c|c}
$\begin{array}{c}\text { Breast density cate- } \\
\text { gory }\end{array}$ & $\begin{array}{c}\text { Malignancy/total in } \\
\text { BI-RADS 4a }\end{array}$ & $\begin{array}{c}\text { Malignancy/total in } \\
\text { BI-RADS 4b }\end{array}$ & $\begin{array}{c}\text { Malignancy/total in } \\
\text { BI-RADS 4c }\end{array}$ & $\begin{array}{c}\text { Malignancy/total in } \\
\text { BI-RADS 4 }\end{array}$ \\
\hline A & $2 / 3$ & $10 / 10$ & $9 / 10$ & $21 / 23$ \\
\hline B & $5 / 13$ & $20 / 24$ & $9 / 9$ & $28 / 42$ \\
\hline C & $3 / 15$ & $16 / 18$ & $4 / 4$ & $9 / 12$ \\
\hline D & $2 / 5$ & $3 / 3$ & $31 / 32$ & $92 / 123$ \\
\hline
\end{tabular}
odds ratio.

Table №7. Details of mammographic shape and margin, its positive predictive values and

\begin{tabular}{|c|c|c|c|c|c|c|}
\hline \multirow{2}{*}{$\begin{array}{c}\text { Mammographic } \\
\text { morphological features }\end{array}$} & \multicolumn{3}{|c|}{ BI-RADS category } & \multirow[b]{2}{*}{$\begin{array}{l}\text { BI-RADS } \\
\text { 4(PPV) }\end{array}$} & \multirow[b]{2}{*}{ OR(95 \% CI) } & \multirow[b]{2}{*}{ P VALUE } \\
\hline & $\begin{array}{l}\text { BI-RADS } \\
\text { 4A(PPV) }\end{array}$ & $\begin{array}{l}\text { BI-RADS } \\
\text { 4B(PPV) }\end{array}$ & $\begin{array}{l}\text { BI-RADS } \\
\text { 4C(PPV) }\end{array}$ & & & \\
\hline \multicolumn{7}{|l|}{ Mass shape } \\
\hline - $\quad$ Round & $0(0)$ & $0(0)$ & $0(0)$ & $0(0)$ & - & - \\
\hline - Oval & $19(26.3)$ & $21(90.5)$ & $8(100)$ & $48(66.7)$ & $0.50(0.22-1.1)$ & 0.05 \\
\hline - Irregular & $17(41.2)$ & $34(88.2)$ & $24(95.8)$ & $75(80.0)$ & $2(0.87-4.56)$ & 0.049 \\
\hline \multicolumn{7}{|l|}{ Mass margin } \\
\hline $\begin{array}{l}\text { - Well } \\
\text { circumscribed }\end{array}$ & $4(50)$ & $1(0)$ & $0(0)$ & $5(40.0)$ & $0.2(0.03-1.3)$ & 0.048 \\
\hline - $\quad$ Microlobulated & $4(25)$ & 12(91.7) & $14(100)$ & $30(86.7)$ & $2.6(0.85-8.35)$ & 0.047 \\
\hline - $\quad$ Masked & $12(33.3)$ & $14(85.7)$ & $7(85.7)$ & $33(66.7)$ & $0.57(0.24-1.3)$ & 0.106 \\
\hline - Indistinct & $16(31.2)$ & $23(91.3)$ & $8(100)$ & $47(72.3)$ & $0.81(0.35-1.8)$ & 0.311 \\
\hline - $\quad$ Spiculated & $0(0)$ & $5(100)$ & $3(100)$ & $8(100)$ & $6.33(0.35-113)$ & 0.209 \\
\hline
\end{tabular}

$31(25.2 \%)$ benign outcomes. A statistically significant difference in the rate of breast cancer diagnosis noted between BI-RADS 4A and 4B subgroups (details in table 3 ). Our analysis yielded cancer predictive probability (PPV) of 34\% for $4 \mathrm{~A}$, $89 \%$ for $4 \mathrm{~B}$ and $97 \%$ for $4 \mathrm{C}$. Infiltrating ductal carcinoma (IDC) was the commonest pathological subtype (85 out of 92) malignancy.

The average age of the study population is $(47.2+11$ years). Women in the BI-RADS 4c sub- group were older (mean age $50.2+12.2$ years) than women with BI-RADS $4 a$ (mean age $44.7 \pm$ 10.3 years) and $4 \mathrm{~b}$ (mean age $47.2+10.4$ years) subgroups respectively. None of the BI-RADS $4 a$ patients were malignant in less than 40 years of age group. Out of 50 postmenopausal patients, 41 are malignant. Postmenopausal status and older age were significant predictive factors for malignancy outcomes in the BI-RADS 4a group (7 out of 12). The age-wise distribution of the BI-RADS 4 
sub-classification score and its outcome were given in Table 4. Clinical features of the study population at presentation and its pathological outcomes were given in Table 5 .

$12 \%$ of patients have a family history of breast cancer in the malignant cohort. The average size of the malignant mass was $(39.5+16.3 \mathrm{~mm})$ and benign mass was $(37+21.2 \mathrm{~mm})$. The average size of the mass in BIRADS $4 c(44+16 \mathrm{~mm})$ was more compared to the rest of BI-RADS $4 \mathrm{a}(32+9.7 \mathrm{~mm})$ and BIRADS $4 \mathrm{~b}$ $(39+17 \mathrm{~mm})$. Breast density distribution its BIRADS score and the pathological outcome were given in Table 6.

Tumor morphology was described according to BI-RADS 5th edition descriptors into mass shape, mass margin, nature of microcalcification and additional findings such as architectural distortion, skin thickening, mass density, and lymph node. The comparative frequency, PPV for carcinoma as a function of BI-RADS morphological descriptors in BI-RADS 4 subgroups were shown in Tables 7 and 8 .

A breast lump was more common on the right side $(55.3 \%)$ than on the left side $(43.9 \%)$. One of our patients had bilateral malignant mass at presentation. The right upper outer quadrant $(31.5 \%)$ was the commonest location of the malignant mass followed by the left upper outer $(22.8 \%)$. Satellite nodules were seen not seen in the BI-RADS 4 a group.

Discussion.

Indication of biopsy for a suspicious mammographic finding is multi-factorial and the BIRADS score remains the single most important variable in predicting cancer diagnosis. Other factors like patient preference and the anxiety associated with nonintervention may drive a patient to undergo a biopsy even if the probability of cancer is low.

BI-RADS 4 category has been subdivided into three subgroups based on degree suspicion of malignancy but subcategorization is subjective and based on clinical experience and preference of radiologist and no objective criteria have been defined for this. In our study, PPV for BI-RADS $4 \mathrm{a}$, $4 \mathrm{~b}$ and $4 \mathrm{c}$ were $34 \%, 89 \%$, and 97\%. Although these observations appear clinically correct but were statistically different from BI-RADS 5TH edition recommendations. Possible explanations for such a discrepancy include isolated different observations secondary to sample size, patient distribution, and selection bias. Other causes may be nonrigid / nonexplicit BI-RADS recommendations leading to inappropriate categorizations in BIRADS 4 subgroups, like some of the lesions classified as BI-RADS 4 a may belong to BI-RADS $4 \mathrm{~b}$ or 4c. Similar difference in observation was also quoted in the past by Lazarus et al 2006(PPV for $4 a=5.6 \%, 4 b=50 \%$, and $4 c=33.3 \%$ ) and Leblebici
$2014(4 a=6 \%, 4 b=15 \%$, and $4 c=53 \%)[9,10]$. So it might be suggested for rigid and explicit morphological criteria for differentiating different BI-RADS subgroups so that it will be less subjective. Furthermore, objective morphological criteria might help in computer-assisted reporting and development of robust artificial intelligence in mammography.

In our study, the median age of the study group was $47.2+11$ years. BI-RADS 4 a patients tend to be younger than BI-RADS $4 \mathrm{~b}$ and $4 \mathrm{c}$ which is similar to earlier observations[11]. A significant difference in predictive value observed in less than 40 year age group where all BI-RADS $4 a$ assessment category were benign emphasizing reduced sensitivity of mammography in this age group so additional imaging follow up such as ultrasound or breast MRI may be used as a supplement in these age group with BI-RADS $4 \mathrm{a}$ assessment which may reduce unnecessary biopsy and surgery [12].

Attending menopause as such does not cause cancer, but the risk of breast cancer development increases as a woman age she is exposed to estrogen for a longer duration. So women who have been through natural menopause are twice more likely to develop cancer [13]. Postmenopausal status showed a significant association with malignancy outcomes in our study (41 out of 50 postmenopausal ladies had cancer). In the subgroup of BI-RADS 4 a overall incidence for cancer diagnosis increases from $34 \%$ to $59 \%$ if we club BI-RADS 4 a with postmenopausal status with similar results quoted by Leblebici et al [10].

Location of the mass lesion and its impression on adjacent breast tissues is also a significant factor affecting cancer detection on mammography. The highest number of malignant lesions in our study BI-RADS 4 lesions were located in the right upper outer quadrant $(32 \%)$ which is similar to the occurrence of breast cancer commonly in the upper-outer quadrant. This is consistent with the results by Naeem et al [14].

Breast density is a major factor for breast screening \& diagnosis. BI-RADS 5th edition classification assigns mammographic breast density into 4 categories: a-entirely fatty, b-Scattered areas of fibro glandular density, c- Heterogeneously dense \& d-Extremely dense. In the present study, BI-RADS $4 a$ showed the greatest variation in diagnostic accuracy with $67 \%$ detection rate in category a breast compared to $20 \%$ in category c and $40 \%$ in category d breast density respectively. As a dense breast obscures the subtle finding which makes the detection of early breast cancer more difficult resulting in lower sensitivity $\&$ higher rate of interval cancer detection [15]

Presurgical evaluation of breast tumor size is important for choosing appropriate treatment plans, especially with the advent of neoadjuvant 
Table №8. Additional mammographic observations, its positive predictive value and Odds ratio.

\begin{tabular}{|c|c|c|c|c|c|c|}
\hline & \multicolumn{3}{|c|}{ BI-RADS category } & \multirow[b]{2}{*}{$\begin{array}{l}\text { BI-RADS } \\
\text { 4(PPV) }\end{array}$} & \multirow[b]{2}{*}{ OR(95 \% CI $)$} & \multirow[b]{2}{*}{$\begin{array}{l}\text { P } \\
\text { VALUE }\end{array}$} \\
\hline & $\begin{array}{l}\text { BI-RADS } \\
\text { 4A(PPV) }\end{array}$ & $\begin{array}{l}\text { BI-RADS } \\
\text { 4B(PPV) }\end{array}$ & $\begin{array}{l}\text { BI-RADS } \\
\text { 4C(PPV) }\end{array}$ & & & \\
\hline \multicolumn{7}{|l|}{$\begin{array}{l}\text { Additional mammographic } \\
\text { observations }\end{array}$} \\
\hline - Skin changes & $9(22.2)$ & $21(85.7)$ & 14(100) & 44(77.3) & $1.23(0.51-2.92)$ & 0.64 \\
\hline - Architectural distortion & $6(33.3)$ & $14(92.8)$ & 11(100) & $31(83.9)$ & $2.05(0.71-5.90)$ & 0.18 \\
\hline - Axillary adenopathy & $6(50)$ & $14(85.7)$ & 13(100) & $33(84.9)$ & $2.27(0.79-6.53)$ & 0.13 \\
\hline - microcalcifications & $5(0)$ & 17(100) & 13(100) & $35(85.7)$ & $2.51(0.88-7.20)$ & 0.08 \\
\hline - $\quad$ Satellite nodules & $0(0)$ & $3(100)$ & $5(100)$ & $8(100)$ & $6.34(0.35-113)$ & 0.21 \\
\hline \multicolumn{7}{|l|}{ Mass density } \\
\hline - Isodense & $22(22.7)$ & $24(85.7)$ & $12(100)$ & $58(65.5)$ & $0.39(0.16-0.9)$ & 0.0139 \\
\hline - Hyperdense & $14(35.7)$ & 31(90.3) & $20(95.0)$ & $65(80.0)$ & $2.58(1.1-6.01)$ & 0.0138 \\
\hline
\end{tabular}

therapy and minimal radical surgeries. Both breast ultrasound and x-ray mammography tend to underestimate the breast tumor size, while clinical assessment often overestimates it [16]. In our study, the mean size of the BIRADS $4 \mathrm{c}$ is greater than BI-RADS $4 \mathrm{a}$ and BI-RADS 4b. Larger average tumor size in our study was observed compared to median tumor size of $2.23 \mathrm{~cm}$ in earlier studies by CholatipWiratkapun et al possibly represents delayed detection due to lack of population-based screening programs in our region and the selection of only palpable breast lesions in the present study [17].

Radiologically, round to oval masses with internal fat content (hypodense) and the welldefined margin is mostly associated with benign breast lesions. Isodensity of mass with lobulated obscured and indistinct margins are classified as suspicious. Highly suspicious lesions tend to be mostly of higher in density, irregular shape, spiculated, and indistinct margins [18]. However, around $10 \%$ of malignant lesions may show overlapping or benign features such as round, oval shape, and well-defined margin. Sometimes spicu- lations in the mass margin and adjacent parenchymal changes may be too subtle to demonstrate. These scenarios may lead to potentially malignant breast lesions being overlooked or misinterpreted, with wrong interpretation accounting for $52 \%$ of errors in mammography [19]. In the present study irregular and lobulated oval shape with obscured or masked margin was the commonest pattern in BI-RADS 4A. But an irregular shape with microlobulation or spiculations was common for BI-RADS 4c lesions. Isodensity of the mass with surrounding parenchyma common in BI-RADS $4 \mathrm{a}$ subgroup which reduced PPV of $22.7 \%$ in isodense mass subgroup compared to PPV of $35.7 \%$ in hyperdense mass lesions of BIRADS 4a. This is consistent with the earlier described literature [18].

In the present study spiculated margin, microcalcifications, architectural distortions, and satellite nodules were common in BI-RADS 4b and $4 \mathrm{c}$ subcategories which showed significant statistical association with malignant outcomes with similar result quoted in earlier observation [18, 19]. Microlobulation of margin is a suspicious ma- 


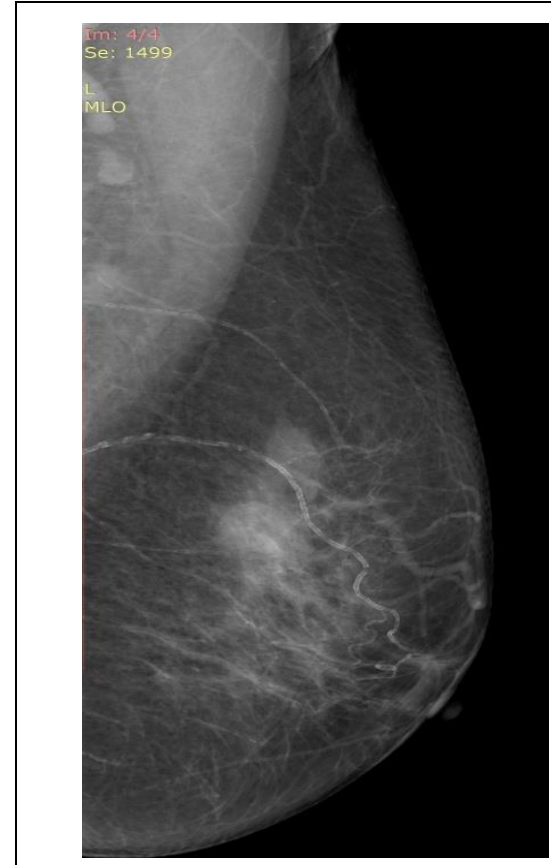

Fig. 1 a (Рис. 1 a)

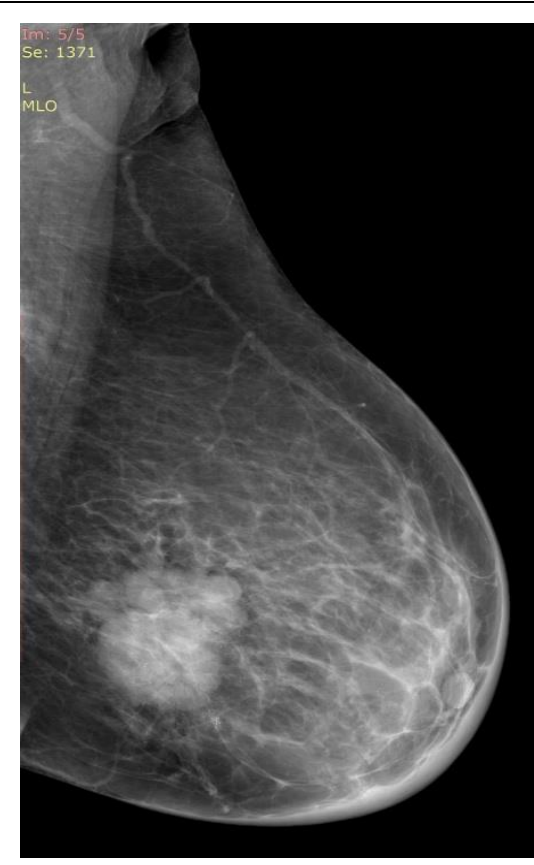

Fig. 1 b (Рис. 1 б)

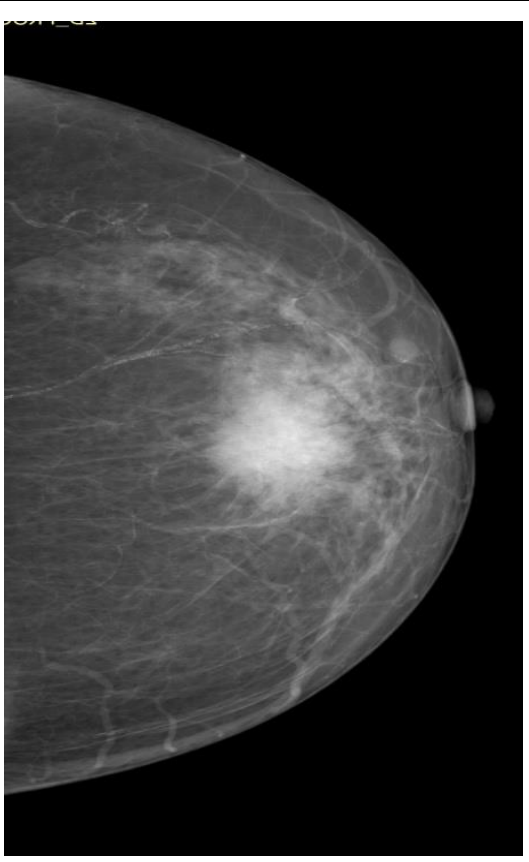

Fig. 1 в (Рис. 1 с)

Fig. 1. Demonstrating imaging features in BI-RADS 4 sub-categories (4A, 4B AND 4C).

A - Irregular mass with obscured margin, B - Oval mass with microlobulation, C - Irregular mass with indistinct and speculation

Рис. 1. Аемонстрация особенностей визуализации в поАразделах BI-RADS 4 (4A, 4B и 4C).

А - Объемное образование с завуалированным краем, Б - Овальное образование с мелкодольчатым строением, В - Объемное образование с нечеткими спикулообразными контурами

lignant descriptor that showed an association with triple-negative breast cancer (Kojima y et al) [20]. Microlobulation also showed a high PPV for malignancy outcomes in the present study. Our study because of retrospective nature didn't have the final postsurgical immunohistochemical analysis to stratify the hormone receptor status.

Microcalcifications in breast result from calcium oxalate and calcium phosphate deposition in the parenchyma or ducts. Calcium oxalate is produced by apocrine cells which seen more frequently with benign breast conditions but can also be seen less commonly with malignancy. Calcium phosphate is more often associated with malignant breast lesions than calcium oxalate [21]. Mammographic detection of microcalcifications with characteristic shape and location is crucial to the diagnosis of breast carcinoma [22]. However, mammography can demonstrate breast microcalcifications in only $30 \%-50 \%$ of breast cancers. In the present study, diffuse and segmental microcalcifications were present in 5 cases in BI-RADS 4a without any malignant outcome. Pleomorphic and fine linear branching patterns of microcalcification were seen in 30 cases in BI-RADS $4 \mathrm{~b}$ and $4 \mathrm{c}$ with all lesions being malignant.

The limitation of our study was its retrospective design and the sampling method which was purposive with selection bias. Other limita- tions were its smaller sample size and lack of follow up treatment and post-surgical outcomes.

\section{Conclusion.}

Our study is a retrospective record-based study to analyze the outcome and predictive values of the BI-RADS 4 subcategories and individual morphological appearances, despite possible limitations we conclude with the followings.

Learning points:

- BI-RADS 4a patients tend to be younger with smaller mass size at the presentation compared to BI-RADS 4c.

- Young patients with less than 40 years of age in BI-RADS 4 a category have more benign outcome.

- BI-RADS 4b, 4c and old patients (more than 40 years) with 4 a require immediate biopsy.

- In young patient less than 40 years age with BIRADS 4 a score may require additional imaging like ultrasound or breast magnetic resonance imaging (MRI) or close follow up.

- Additional imaging observations like microcalcifications, skin thickening, architectural distortion and lymphadenopathy are worrisome essentially upgrades the BI-RADS score.

- BI-RADS assessment categorization is subjective but with the advancement of knowledge, objective criteria definition is required. 


\section{RUSSIAN ELECTRONIC JOURNAL OF RADIOLOGY}

\section{References:}

1. Malvia S., Bagadi S.A., Dubey U.S., Saxena S. Epidemiology of breast cancer in Indian women. Asia Pacific Journal of Clinical Oncology. 2017; 13(4): 289-95.

2. Shrestha M.K., Ghartimagar D., Ghosh A., Shrestha E., Bolar $P$. Significance of quadruple assessment of breast lump-A Hospital based study. Journal of Pathology of Nepal. 2014. 24; 4(8): 630-4.

3. Pace L.E., Keating N.L. A systematic assessment of benefits and risks to guide breast cancer screening decisions. JAMA. 2014; 311: 1327-35.

4. D'Orsi C.J., Sickles E.A., Mendelson E.B. et al. ACR BI-RADS Atlas, Breast Imaging Reporting and Data System. Reston, VA: American College of Radiology, 2013.

5. Puliti D., Duffy S.W., Miccinesi G. et al. Overdiagnosis in mammographic screening for breast cancer in Europe: a literature review. J Med Screen. 2012; 19: 42-56.

6. Hubbard R.A., Kerlikowske K., Flowers C.I., Yankaskas B.C., Zhu W., Miglioretti D.L. Cumulative probability of false-positive recall or biopsy recommendation after 10 years of screening mammography: a cohort study. Ann Intern Med. 2011; 155:48192.

7. Flowers C.I., O'Donoghue C., Moore D. et al. Reducing falsepositive biopsies: a pilot study to reduce benign biopsy rates for BI-RADS $4 A / B$ assessments through testing risk stratification and new thresholds for intervention. Breast Cancer Res Treat. 2013; 139: 769-77.

8. Alagaratnam T.T., Wong J. Limitations of mammography in Chinese females. Clinical radiology. 1985; 1-36 (2): 175-7.

9. Lazarus E., Mainiero M.B., Schepps B., Koelliker S.L., Livingston L.S. BI-RADS lexicon for US and mammography: interobserver variability and positive predictive value. Radiology. 2006; 239 (2): 385-91.

10. Leblebici I.M., Bozkurt S., Eren T.T., Ozemir I.A., Sagiroglu J., Alimoglu O. Comparison of clinicopathological findings among patients whose mammography results were classified as category 4 subgroups of the BI-RADs. Northern clinics of Istanbul. 2014; 1 (1):1.

11.Chaiwerawattana A., Thanasitthichai S., Boonlikit S., Apiwanich C., Worawattanakul S., Intakawin A., Rakiad S., Thongkham K. Clinical outcome of breast cancer BI-RADS 4 lesions during 2003-2008 in the National Cancer Institute Thailand. Asian Pacific Journal of Cancer Prevention. 2012; 13 (8): 4063-6.
12. Strobel K., Schrading S., Hansen N.L., Barabasch A., Kuhl C.K. Assessment of BI-RADS category 4 lesions detected with screening mammography and screening US: utility of MR imaging. Radiology. 2015; 274 (2): 343-51.

13. Cooper K. Springhouse: Springhouse Corp; 1998. Pathophysiology Made Incredibly Easy.

14. Naeem M., Khan N., Aman Z., Nasir A., Samad A., Khattak A. Pattern of breast cancer: experience at Lady Reading Hospital, Peshawar. J Ayub Med Coll Abbottabad. 2008; 1:20 (4): 22 5.

15. Winkel R.R., von Euler-Chelpin M., Nielsen M., Petersen K., Lillholm M., Nielsen M.B., Lynge $E$ et al. Mammographic density and structural features can individually and jointly contribute to breast cancer risk assessment in mammography screening: a case-control study. BMC cancer. 2016; 16 (1): 414.

16. Bosch A.M., Kessels A.G., Beets G.L., Rupa J.D., Koster D., van Engelshoven J.M., von Meyenfeldt M.F. Preoperative estimation of the pathological breast tumour size by physical examination, mammography and ultrasound: a prospective study on 105 invasive tumours. European journal of radiology. 2003; 48 (3): 285-92.

17. Wiratkapun C., Bunyapaiboonsri W., Wibulpolprasert B., Lertsithichai $P$. Biopsy rate and positive predictive value for breast cancer in BI-RADS category 4 breast lesions. Medical journal of the Medical Association of Thailand. 2010; 93 (7): 830.

18. Popli M.B. Pictorial essay: Mammographic features of breast cancer. Indian Journal of Radiology and Imaging. 2001; 11 (4): 175.

19. Bird R.E., Wallace T.W., Yankaskas B.C. Analysis of cancers missed at screening mammography. Radiology. 1992; 184 (3): 613-7.

20. Kojima Y, Tsunoda H. Mammography and ultrasound features of triple-negative breast cancer. Breast Cancer. 2011; 18 (3): 146-51.

21. Winston J.S., Yeh I.T., Evers K., Friedman A.K. Calcium oxalate is associated with benign breast tissue: can we avoid biopsy? American journal of clinical pathology. 1993; 100 (5): 48892.

22. Morgan M.P., Cooke M.M., McCarthy G.M. Microcalcifications associated with breast cancer: an epiphenomenon or biologically significant feature of selected tumors. Journal of mammary gland biology and neoplasia. 2005; 10 (2): 181-7.. 